\title{
FACTUAL AND THEORETICAL STATUS OF THE MEMORY DEVELOPMENT PARALLELOGRAM
}

\author{
STATUS FACTUAL E TEÓRICO DO PARALELOGRAMO DO \\ DESENOLVIMENTO DA MEMÓRIA
}

\author{
Boris G. Meshcheryakov ${ }^{1, *}$ (D)
}

\begin{abstract}
A. N. Leontiev coined the term "Memory Development Parallelogram" (MDP) with regard to the basic graphic representation of the results of his macro-ontogenetic research on the memorization of words. Since the 1990s, Russian psychological journals published many articles that challenged the term MDP, denying it as a real fact, a supposed "failure" of Leontiev's research. In this article, we refute this idea by means of bibliographical as well as empirical studies, aiming to establish that MDP was not the only way the author has represented memory.
\end{abstract}

Keywords: Cultural-historical and activity theory. L. S. Vygotsky. A. N. Leontiev. Memory Development Parallelogram. Memory.

RESUMO: A. N. Leontiev cunhou o termo "Paralelogramo do Desenvolvimento da Memória” (PDM) considerando a representação gráfica básica dos resultados de sua pesquisa macroontogênica sobre a memorização de palavras. Desde os anos 1990, periódicos russos sobre psicologia têm publicado muitos artigos que contestam o termo PDM, negando que represente um fato real e considerando-o uma suposta "falha" da pesquisa de Leontiev. Neste artigo, refutamos tal ideia por meio de estudos bibliográficos e empíricos, com o objetivo de estabelecer que o PDM não foi a única forma de o autor representar a memória.

Palavras-chave: Teoria cultural-histórica e da atividade. L. S. Vygotsky. A. N. Leontiev. Paralelogramo do Desenvolvimento da Memória. Memória.

1.Dubna State University - Dubna, Russia.

*Correspondence author: borlogic1@gmail.com

Dossier organized by: Gisele Toassa and Ana Luiza Bustamante Smolka 


\section{Introduction}

It is well-known that, in the mid-1920s, L. S. Vygotsky, along with A. N. Leontiev and A. R. Luria, began to develop a completely new view about mental functioning. Their central idea was that a person's mental functions (processes), historically and ontogenetically speaking, do not remain unchanged in their natural immediacy. Rather, similarly to what happens with other activities through the help of physical tools, they develop, improve, and become purposeful actions carried out with the help of psychological tools-a variety of symbolic means. Consequently, mental development is one of the most important spheres of people's cultural development. This large idea opened a wide field of research on the formation and development of mediated mental processes, through mastering various psychological tools, including objects, paintings, gestures, language, number systems, and other special systems of signs and symbols.

This article specifically addresses the concept introduced by A. N. Leontiev into psychology (LEONTIEV, 1931; LEONTIEV et al., 2003): the "Memory Development Parallelogram" (MDP)1. Clear signs of the problem can be noted in the fact that, beginning in the 1990s, several publications appeared in leading Russian psychological journals in which MDP began to be denied as a real fact (LOKHOV et al., 1993). This concept is even considered a "failure" in Leontiev's research, which also was a reason for breaking up the partnership between A. N. Leontiev and L. S. Vygotsky (MYASOED, 2003; 2010; 2013). In addition, there is also some confusion regarding the understanding of MDP as fact or as principle.

One could, and should, separate at least two meanings found in the original source: 1) empirical facts and patterns, which were demonstrated by A.N. Leontiev for the first time in his research (actually MDP); and 2) theoretical ideas (statements) used to interpret those facts ("the development parallelogram principle" or "parallelogram principle") ${ }^{2}$. A. N. Leontiev clearly presented the content of these theoretical ideas in his brief preface "Author's note". "The proposed work represents the experience of a monographic study based on the fundamental principles of the theory of the historical development of higher forms of behaviour, first proposed by L. S. Vygotsky, and developed in recent years in collaboration with A. R. Luria and us" (LEONTIEV et al., 2003, p. 32).

In addition, there is a third meaning for the hypothetical ideal MDP model, which presumably can be derived from the theory of higher mental functions (HMF) development when compared with the real data. If A. N. Leontiev actually made a logical deduction about the MDP model based on L. S Vygotsky theory of HMF development and then took this ideal model as a hypothesis of his research, then it could be said that he enriched the theory with a non-trivial model, which he intended to test. The logical reconstruction of A. N. Leontiev's research shows that the situation was somewhat more complicated.

In order to clarify, it is necessary to point out that there are at least two types of MDP (which are represented in a variety of ways) in A. N. Leontiev's work: 1) macrogenetic-which is established in a cross-sectional study with ages ranging from the younger pre-schooler group to adult students-; and 2) microgenetic - which is established in a formative individual experiment on mentally retarded children. Here, we will discuss the problems associated with macrogenetic MDP. The main goal is to separate the real empirical and theoretical picture of Leontiev's study from distortions that later appeared in the critical literature about his work.

\section{How Are the Facts Described?}

The term "parallelogram development" usually refers to a visual representation (Fig. 1) of the main trends in the development of higher mediated mental functions (ZAPOROZHETS; ELKONIN, 1983, p. 67). 


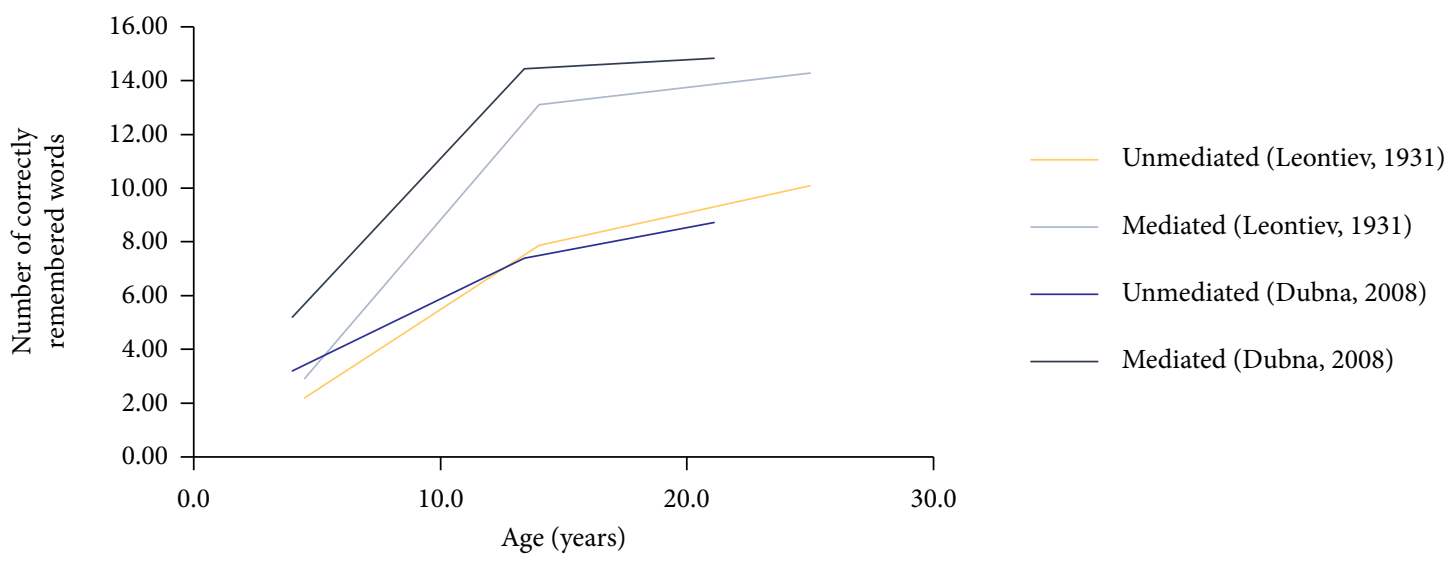

Figure 1. Graphic representation of Leontiev's data (1931), and replication data (MESHCHERYAKOV et al., 2008).

A. N. Leontiev used at least three types of description: 1) a memorization table composed by descriptive statistics (mean, median, mode, average error); 2) a table of relations of the average number of correctly reproduced words either with or without pictures; and 3) a verbal description of the found empirical regularity:

The general pattern that emerges here could be formulated this way: beginning from preschool age, the developmental rate of memorization with the help of external means is much higher than the developmental rate of memorization without the help of cards; and vice versa, starting from the first school age, the increase in indicators of externally direct memorization is faster than a further increase in mediated memorization (LEONTIEV et al., 2003, p. 83).

It is clear that the semantic center of this description is the statement about the heterochrony of the growth rates of memorization indices in two experimental conditions: in preschool age, the indicator of externally mediated memorization increases faster, V1 (compared to the externally direct memorization indicator, V0, as seen in note 4). The opposite happens in the first school age (Table 1).

The same pattern can be described differently: the relation of the V1 and the V0 indicators as a function of age (as well as a function of cultural development) has the form of an inverted U-shaped function; that is, at preschool age, it grows, but, somewhere at the beginning of school age, it begins to decrease. In analyzing the data, A. N. Leontiev used the "coefficient of relative increase": $k=(\mathrm{V} 1-\mathrm{V} 0) / \mathrm{V} 0$ (the value of which is just 1 less than the value of the relation of the V1 and the V0 indicators). A. N. Leontiev gives the following coefficients of relative increase (k) (LEONTIEV et al., 2003, p. 81):

Table 1. The coefficients of relative increase (k) for different age groups (Leontiev, 2003).

\begin{tabular}{cccccccc}
\hline \multirow{2}{*}{$\begin{array}{c}\text { Test } \\
\text { group }\end{array}$} & \multicolumn{2}{c}{ Preschoolers } & \multicolumn{2}{c}{ The first school age } & The second school age & Students \\
\cline { 2 - 7 } & $\begin{array}{c}\text { Age } \\
\text { 4 to 5 }\end{array}$ & $\begin{array}{c}\text { Age } \\
\text { 6 to } 7\end{array}$ & $\begin{array}{c}\text { I-II groups } \\
\text { (age 7 to 12 age) }\end{array}$ & $\begin{array}{c}\text { III-IV groups } \\
\text { (age 10 to 14) }\end{array}$ & $\begin{array}{c}\text { V-VI groups } \\
\text { (age 12 to 16) }\end{array}$ & $\begin{array}{c}\text { Age } \\
\text { (a) to 28 }\end{array}$ \\
\hline $\mathrm{k}$ & 0,38 & 0,72 & 0,82 & 0,71 & 0,66 & 0,42 \\
\hline
\end{tabular}

It is obvious that the coefficients of relative increase presented in the table confirm the general pattern as formulated. Regarding the degree of generality of this pattern, it should be noted that it may 
be limited to the means of external mediation. Experiments in which pictures were replaced by letters suggested that the MDP moves on the age scale to the right. Moreover, in preschoolers aged 4 to 5 and 6 to 7 , indicators of externally mediated memorization are significantly lower than without external mediation (MESHCHERYAKOV et al., 2008). Replacing pictures with letters (mnemonics of the first letter) allowed Leontiev to identify a long initial period, when that method not only did not help, but also hindered memorization (Fig. 2). It is also remarkable that, for letter mediation, the general pattern established by A. N. Leontiev as the rate of development turned out to be generally fair.

The comparison of these different ways of describing data leads to the conclusion that they are not equivalent. Thus, the question is: "Which of the four forms of presentation of results is considered pertinent, and which are expendable?" The most frequently discussed graphic form is the "parallelogram". A. N. Leontiev convincingly showed that this form of representation can vary greatly under the influence of various experimental factors. The author, thus, defined the ("underlying") pattern:

[T] he graphic form of expression of this relationship may be more or less flexible, but the underlying law remains unchanged. We can find it in our trial experiments, and in the present research, as well as in the research of memorization by adults who belong to different cultural levels, and in the research of the mediated attention development in children, and, finally, through a longterm study of memorization development in individual subjects (LEONTIEV et al., 2003, p. 84).

It is interesting to analyze some examples of how A. N. Leontiev acquired data, as well as of how other researchers described those data.

Let us start with an example which does not use the name "parallelogram". P. P. Blonsky, in his book Pedology, for pedagogical students (1934 [2006], p. 300), adopts two forms of data presentation also used by A. N. Leontiev: graphic representation and a table of memorization indicators (and their ratios). Blonsky briefly presents A. N. Leontiev's research: the "parallelogram of development," the idea of "internalization," and even internally mediated memorization are not mentioned at all, and the lower curve on Leontiev's graphic is called "natural memory development curve" (a term that is not at all appropriate for verbal voluntary memory). P. P. Blonsky characterizes "mediated memory" as the use of external aids to memorization: books, notebooks, tables, notes, etc. Additionally, the main result of A. N. Leontiev's research on memory is described as follows: "[...] it turns out that, in the older preschool age, so-called mediated memory develops rapidly, at a faster

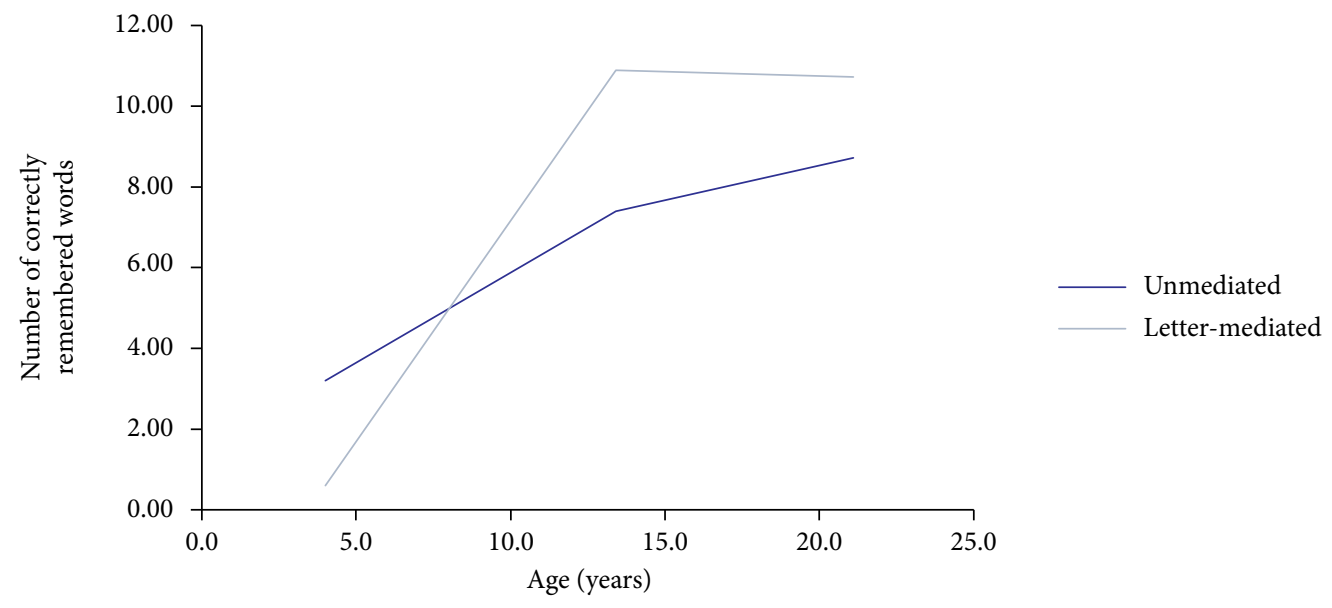

Figure 2. Replacing pictures with letters (mnemonic of the first letter) allowed to identify a initial period when that mediation creates difficulties. 
rate (almost 1.5 times faster) than natural memory" (BLONSKY, 2006, p. 299).

One of the most complete descriptions of A. N. Leontiev's entire research is presented by A. V. Zaporozhets and D. B. Elkonin (1979). Such authors did not confine themselves to describing only macrogenetic research (in their terminology, comparative-genetic), but also ascribed great value to its continuation in the "formative experiment", noting that it was "the first and only study of an experimental genetic type at this stage in the development of the theory" (ZAPOROZHETS; ELKONIN, 1979, p. 15).

MDP is regarded as one of $\mathrm{A}$. N. Leontiev's discoveries:

The first discovery can be outlined as follows. The so-called discovery "parallelogram of development" was obtained by comparing the relation between the processes of direct memorization and mediated memorization at different ages (preschool, school, and in adults). Its essence lies in two results: the first was that, at the beginning and ending points-i. e., in the youngest children and in adults-, there are no significant differences between the results of direct and mediated memorization using external means (pictures). The second result showed that, in the middle between these poles (that is, at school age), there are large differences between these two forms of memorization. Indirect memorization is much more productive than mediated memorization. The developmental curves of the two forms of memorization progress in such a way that, in the first half, direct memorization does not reveal noticeable shifts, while mediated forms give significant shifts and, conversely, in the second half, the mediated forms do not significantly move, while direct memorization does. The researchers should have attempted to explain these results somehow. On the basis of these results, they suggested that the rise of direct memorization productivity in the second half of the curve is due to the transformation of direct forms into mediated forms, when direct memorization disappears, turning into hidden internally mediated memorization, using internal means rather than external ones (ZAPOROZHETS; ELKONIN, 1979, p. 15).

Two controversial points should be noted in this description. First, the excessive idealization of the graphic form of the MDP (see the aforementioned first result). Leontiev would not agree with this argument (as exposed ahead).

Secondly, the statement that the idea of transforming direct forms into mediated ones originated as a hypothesis after A. N. Leontiev discovered that MDP (i.e., just in interpretation of the results) is also controversial. In our opinion, the idea of "the transformation of direct forms into mediated forms" was included in the theoretical foundations on which A. N. Leontiev relied before undertaking the research, and it was also contained in the research hypothesis. However, A. N. Leontiev did not derive the model of the correct parallelogram from this hypothesis either at the preliminary stage or post factum. As far as we know, no one has done so thus far.

The description of the MDP by L. S. Vygotsky is of great interest. Unfortunately, the most appropriate text (History of the development of higher mental functions. Chapter 10: "Development of mnemomic and mnemotechnical functions", in VYGOTSKY, 1983, p. 239-254) contains strange contradictions and inaccuracies, which are left without comments by the editor of this volume of the Collected Edition. Nevertheless, Vygotsky described A. N. Leontiev's results by trying not to idealize the MDP form: “The lower curve, meaning the processes of direct memorization, begins quickly and sharply to ascend to the upper curve and rise further, while the rate of ascension of the upper curve, on the contrary, slows down and levels off somewhat" (VYGOTSKY, 1983, p. 247).

L. S. Vygotsky, therefore, does not claim that "there are no significant differences" at the ends of the 
"parallelogram". He recognizes only the facts of "being drawn up", "a tendency of the curves to converge", etc.

A. N. Leontiev states the remarkable fact that the MDP form is somewhat like the perfect parallelogram, as follows: “Thus, both lines of development in their conventional graphic representation are two curves approaching each other in the lower and upper limits, and forming a shape that, in its form, resembles the figure of a not completely regular parallelogram with two clipped corners" (LEONTIEV et al., 2003, p. 83, emphasis inserted); "Hereinafter we will briefly denote this pattern of memorization development by the conditional term 'development parallelogram"' (LEONTIEV et al., 2003, p. 87-88).

These characteristics mean that the concept established by A. N. Leontiev can be called a "parallelogram" only metaphorically; that is, figuratively (see also MESHCHERYAKOV et al., 2008; MESHCHERYAKOV, 2013), and should have properly been called Leontiev's parallelogram. The basis for choosing the name "parallelogram", perhaps, was a distant, but very inspiring, analogy with the well-known principle (or rule) of mechanics: the parallelogram of forces. However, looking at A. N. Leontiev's graphics, it would be possible to invent some other, much more accurate name than "parallelogram", since this concept includes both a rectangle and a square, which do not correspond at all to the detected empirical regularity. Beyond that, if we graphically present the coefficients of the relative increase $(\mathrm{k})$ as a function of age (stages of cultural development), we get an inverted U-shaped function, which could be called "Leontiev's parabola". (In fact, he also used these graphic representations in his book.)

It is clear that A. N. Leontiev considered these graphics of fundamental theoretical importance, from the point of view of predictions of the theory of HMF development. Hence, let us take the MDP not only as an empirical result, but also as an explanatory principle.

In an article from the year 2003, P. A. Myasoed entitled a whole paragraph as “There is a parallelogram!” It ends with a statement: "A. N. Leontiev had reason to talk about the 'memory development parallelogram" (MYASOED, 2003, p. 111). However, in the next two articles written by this author, the conclusions are contradictory. Myasoed says "Relying on the data, A. N. Leontiev was right to speak about the memory development parallelogram" (MYASOED, 2010, p. 118); and, on the next page: “The parallelogram that A. N. Leontiev looked for does not exist" (MYASOED, 2010, p. 119). After three years, the same author writes: "Such a 'parallelogram' is based on the views of L. S. Vygotsky [...] it does not exist in the original work. But the fact remains, and giving credit to the researcher who discovered it, we can speak of Leontiev's parallelogram" (MYASOED, 2013, p. 113).

If P. A. Myasoed implied that A. N. Leontiev was looking for the perfect parallelogram, then repeating the conclusion about its non-existence does not represent any novelty; it was very clear to L. S. Vygotsky and A. N. Leontiev. However, this trivial affirmation is used to produce another conclusion: "A. N. Leontiev's statement that the ontogeny of memorization obeys the 'parallelogram principle' is not confirmed" (MYASOED, 2003, p. 106; see also p. 116). Then, a very serious conclusion is drawn: "L. S. Vygotsky and A. $\mathrm{N}$. Leontiev went different ways because they disagreed about the proof of the parallelogram principle and the idea of "internalization"” (MYASOED, 2003, p. 114).

Following this path, we genuinely consider there are grounds for criticism of Leontiev's empirical methodology, as well as data analysis. Let us consider some of these problems.

1. There are no images of the auxiliary signs used in the test with mediation.

2. There are broad and overlapping age ranges, which do not allow for simple comparison of discrete age groups.

For example, 12-year-old children in Leontiev's experiment were simultaneously ranged in three "social" groups: schoolchildren I-II (7 to 12 years), III-IV (10 to 14 years), and V-VI (12 to 16 years). Moreover, 
it is not clear how the author distributed the participants in the age ranges.

Leontiev regarded the "education grade level" (not the age) as a basic variable. Nevertheless, this cannot justify his decision, supported by Myasoed as well, to consider the horizontal axis (x) as uniform (i. e., that the data of each age group should be placed at equal distances from each other). From our perspective, it would be extremely desirable to replicate Leontiev's experiment with narrower age groups in order to use the average ages as independent variables.

3. Leontiev did not print the text of instructions for all school series and age groups (there is only an instruction for mediated remembering; see LEONTIEV et al., 2003, p. 78). It is obvious that the instruction for preschool children and first grade schoolchildren would have been different from the one for the last grade and post school students.

4. In order to demonstrate the parallelogram of development, Leontiev used a wide set of age groups: preschool children, schoolchildren, and post school students.

Obviously, in order to construct the parallelogram of development, it was necessary to reduce the age groups to three. The main problem is that the foundations of Leontiev's regrouping are not clear. Why should all schoolchildren be together? It could have been acceptable if the first grade had essentially differed from the last grade, and, in turn, the last grade from the post school students. However, Leontiev did not design the experiment in that way.

One of the aims of our research (MESHCHERYAKOV et al., 2008) was to replicate the classic study carried out by A. N. Leontiev (Fig. 1) on current-day children. Apart from two experimental conditions introduced by A. N. Leontiev (that is, unmediated memorizing and picture-mediated memorizing) our research included another one: letter-mediated memorizing, which made it possible to "shift" the (metaphorical) parallelogram to the right, along the age scale. We constructed the parallelogram on the next three points: younger preschool children, $8^{\text {th }}$ grade schoolchildren, and college students. We constructed the same diagrams as those of A. N. Leontiev's data for three age groups close in age: younger preschool children ( 4 to 5 years), adolescents (12 to 16 years), and post school students.

The following conclusions can be drawn from the results obtained in the study:

1. Age dynamics for reproducing words within unmediated and picture-mediated memorizing is similar to what A. N. Leontiev described (Fig. 1);

2. Leontiev's experimental method has proved to be reliable and resistant to procedural variations;

3. Mediated memory develops faster in present-day preschool children than in children of the 1920s;

4. Applying a more difficult, letter-mediated memorizing method in preschool children results in the reduction of their ability to reproduce words in comparison with direct memorizing (Fig. 2);

5. Studies have shown that children of late preschool and early school age, in a majority of cases, use the first-letter mnemonic rule correctly. However, this does not help them to remember words more effectively. Since mediated memorizing in the stage of acquisition of symbolic means is less effective than direct memorizing, a more appropriate model would be a parallelogram with two "tails" representing the stage of interiorization of operations using mnemonic means. 


\section{"The Parallelogram Principle"}

A. N. Leontiev, relying precisely upon the cultural-historical theory, proposed a qualitative interpretation of the ontogenetic curves of memory productivity for two conditions (memorization with or without the help of pictures) ${ }^{3}$, and, at the same time, he did not claim that Vygotsky's theory accurately predicted the correct parallelogram for the constructed experimental conditions.

We will turn to Leontiev's own text to pose and answer questions: "Has the 'parallelogram principle' been posited as a research hypothesis?"; "Was it derived from Vygotsky's theory?"; "Did the author provide any justification for the acceptability of his research to check the MDP hypothesis?"; "How did A. N. Leontiev formulate a research hypothesis?"

Following Vygotsky and Luria, Leontiev et al. (2003, p. 70) say that, firstly, the hypothesis has a very general and non-operationalized form; there is no hint of any MDP in its formulation. Secondly, it does not assert anything original in comparison with L. S. Vygotsky's main ideas about the development of HMF. Certainly, this hypothesis should be called "Vygotsky's hypothesis", as Leontiev and Sokolova contend. They add that "the development of higher forms of mental processes goes through the use of stimuli-signs" (LEONTIEV et al., 2003, p. 8). Although adopted by A. N. Leontiev, the hypothesis did not give an accurate quantitative prediction of results but, obviously, it was expected that, in the condition without pictures (externally unmediated memorization, as the author accurately writes), older schoolchildren and especially adult students would demonstrate a significant increase in the efficiency of memorization compared to preschoolers and younger schoolchildren. This growth would be due to the development of internally mediated memorization, which, in turn, is due to the previous mastering of external means and methods of memorizing.

A. N. Leontiev did not predict at all that the right-hand fragment of the lower line, reflecting the increase in efficiency of externally unmediated memorization, would be strictly parallel to the line of growth in the efficiency of externally mediated memorization (with pictures) in preschoolers and younger schoolchildren. He also did not predict that the indicators of memorization in the two conditions would be equal in the case of adults. In A. N. Leontiev's formulation of the hypothesis, the fact that the indicators of memorization "move up" in the condition without pictures toward the indicators of memorization in the condition with pictures is very important, and it is difficult to deny, there being, thus, certain grounds for saying that the results are consistent with the hypothesis.

Hence, we note that a rather general hypothesis was originally put forward, which is quite consistent with the dynamics of the relative increase of the coefficients $(\mathrm{k})$ identified, and the form of the metaphorical MDP. This empirical result was elevated to the status of an "empirical law", version confirmed by L. S. Vygotsky: "This phenomenon was first observed while processing experimental material by A. N. Leontiev and he also first formulated the law" (VYGOTSKY, 1983, p. 247).

Ultimately, what does the "the principle of the parallelogram development" mean? A. N. Leontiev says that it is an expression of that law that the development of HMF "happens through the development of memorization with the help of external stimuli-signs" (LEONTIEV et al., 2003, p. 88, emphasis inserted).

Clearly, this formulation means that the "parallelogram principle" is just another name for the same original "Vygotsky hypothesis", but formulated more succinctly than before (as aforementioned).

As already presented, A. N. Leontiev and his colleagues believed that the empirical data that emerged in a macrogenetic study is coherent with "Vygotsky's hypothesis" (i.e., with the results that A. N. Leontiev called the "parallelogram principle"). However, there is another point of view, expressed 
and persistently defended by P. A. Myasoed (2003; 2010; 2013): "Formulated by A. N. Leontiev, the 'parallelogram principle' is not properly confirmed: experimental curves obey different mathematical laws, they do not intersect neither do they indicate two separate lines of ontogenesis" (MYASOED, 2013, p. 116). More specifically, P. A. Myasoed moves on to state two objections: 1) differences in the functions that approximate the upper and lower development curves forming Leontiev's metaphorical parallelogram; and 2) the difference between memorization efficiency for the two conditions (with and without pictures) in adult subjects (students). For us, it does not seem that these arguments are sufficient to baffle A. N. Leontiev and completely discredit the "parallelogram principle".

Firstly, different forms of functions are easily explained from the point of view of the L. S. Vygotsky's theory by the fact that the upper curve does not start at the same phase of development as the lower one, but at a later phase; that is, the initial section is cut off at the upper curve, which the lower one clearly demonstrates (according to A. N. Leontiev, this section reflects purely direct memorization). Secondly, the difference is simply explained by the distinction in the complexity of the tasks themselves. Leontiev was well aware that the task of memorizing with pictures was much easier than memorizing without them (LEONTIEV et al., 2003).

Nevertheless, it is important to understand that the "parallelogram principle" does not explain or predict the exact forms of the functions of memorization indices for the two experimental conditions; in any case, it does not require them to be the same neither does it imply parallelism of these functions. That is why exercises in approximations are crucial. "The principle of the parallelogram" explains the heterochrony of the growth of memory indicators in two conditions as stated in the aforementioned patterns of memory development. Clearly, one can criticize the insufficiency of the "parallelogram principle", but, in the absence of a better explanation, there is no reason to reject it.

Undoubtedly, the idea of "internalization" is covered in the "parallelogram principle" (more precisely, in "Vygotsky's hypothesis"); that is, in the theoretical position of the theory of HMF. However, in his macrogenetic research, A. N. Leontiev did not address the task of testing for the "internalization" hypothesis.

One should be aware that A. N. Leontiev always used the word "internalization" between quotes, obviously, pointing to the metaphorical meaning of the term. It is easy to verify, from the analysis of the text Development of Memory, that the author was well aware that, in a macrogenetic study (cross-sectional), it was absurd to look for the process of "internalization." The analysis of A. N. Leontiev's methodological ideas of the study of "internalization" and its implementation in his microgenetic study using the experimental genetic method deserves a separate article.

\section{Acknowledgement}

The organizers of the dossier would like to thank Lucia Reily for the technical revision of the text in English and thank Juana Marques Pereira Curi for its translation into Portuguese.

\section{Notes}

1. The 2003 edition (LEONTIEV et al., 2003) will be used for citations because of its greater accessibility and maximum proximity to the original edition of A. N. Leontiev (1931).

2. The word "memory" is not part of the term, since the principle is common to different functions. 
3. The name "direct memorization' (another term was "natural memory", as in the case of P. P. Blonsky) is widely used for the condition without pictures, which is extremely unfortunate, due to the fact that, according to A. N. Leontiev's interpretation, in this condition, only preschoolers' and younger students' memorization can be immediate. This is the reason why conceptual dissonance arises when the lower curve of his graphs is called "direct memorization curve." Instead, it should be called "development schedule of internally mediated memorization" (A. N. Leontiev preferred the name "direct external memorization'). Moreover, the upper curve should be called “development schedule of externally mediated memorization' (in which, according to A. N. Leontiev, there are also internal means and methods).

\section{REFERENCES}

BLONSKY, P. P. (1934). Pedologiya [Pedology] and Psikhologiya mladshego shkol'nika [Psychology of the younger schoolchild]. Izbrannyye psikhologicheskiye trudy. Moscow: Izd-vo Mosk. Psikhologosotsial'nogo Instituta/Voronezh: Izd-vo NPO «Modek», 2006. p. 24-459.

LEONTIEV, A N. Razvitiye pamyati: Eksperimental'noye issledovaniye vysshikh psikhologicheskikh funktsiy [Development of memory: Experimental research of higher psychological functions]. // A. N. LEONTIEV. Stanovleniye psikhologii deyatel'nosti: Ranniye raboty / Pod red. A.A. LEONTIEVA; D.A. LEONTIEV; E. E. SOKOLOVA. Moscow: Smysl, 2003. S. 27-206.

LEONTIEV, A. A.; LEONTIEV, D. A.; SOKOLOVA, E. E. Ranniye raboty A N Leont'yeva i ego put' k psikhologii deyatel'nosti [Early works of A N Leontiev and his path to the psychology of activity]. A N LEONTIEV. Stanovleniye psikhologii deyatel'nosti: Ranniye raboty. Trad. A.A. Leontieva; D. A. Leontiev; E. E. Sokolova. Moscow: Smysl, 2003, p. 3-24.

LOKHOV, M. I. et al. Dinamika formirovaniya proizvol'noy pamyati u detey [The dynamics of voluntary memory formation in children]. Psikhologicheskiy zhurnal, v. 14, n. 4, p. 56-65, 1993.

MESHCHERYAKOV, B. G. Kommentariy k stat'ye P. A. Myasoyeda « Onto- i kul'turogenez form zapominaniya: Replikatsiya eksperimentov A.N. Leont'yeva " [Commentary on the article of P. A. Myasoed "Ontological and cultural genesis of forms of memorizing: A replication of Leontiev's experiments”]. Voprosy psikhologii, n. 3, p. 117-118, 2013.

MESHCHERYAKOV, B. G.; MOISEYENKO, E. V.; KONTORINA, V. K. Parallelogramm razvitiya pamyati: Ne mit, no trebuyet utochneniya [The parallelogram of memory development: not a myth, but requires improvement]. Psikhologicheskiy zhurnal Mezhdunarodnogo universiteta prirody obshchestva i cheloveka " Dubna ", n. 1, p. 19-41, 2008. [Elektronnyy resurs]. Available at: http:// www.psyanima.ru. Access: 10 Jan. 2019.

MYASOYED, P. A. "Parallelogramm » A N Leont'yeva, "geneticheskiy zakon » L S Vygotskogo i traditsiya nauchnoy shkoly [Leontiev's "parallelogram", L S Vygotsky's "genetic law" and traditions of a scientific school]. Voprosy psikhologii, n. 2, p. 105-117, 2003.

MYASOYED, P. A. Istoriya, logika i psikhologiya « parallelogramma Leont'yeva » [History, logic and the psychology of "Leontiev's parallelogram"]. Voprosy psikhologii, n. 6, p. 113-125, 2010. 
MYASOYED, P. A. Onto- i kul'turogenez form zapominaniya: Replikatsiya eksperimentov A N Leont'yeva [Ontological and cultural genesis of forms of memorizing: a replication of Leontiev's experiments]. Voprosy psikhologii, n. 3, p. 106-117, 2013.

VYGOTSKY, L S Sobraniye sochineniy: v 6-ti t. T. 3. Problemy razvitiya psikhiki [Collected Works: In 6 T. T.]. Trad. A. M. Matyushkina. Moscow: Pedagogika, 1983. 368 p.

ZAPOROZHETS, A. V.; ELKONIN, D. B. Vklad rannikh issledovaniy A.N. Leont'yeva v razvitiye teorii deyatel'nosti [Contribution of A. N. Leontiev's early research in the development of the theory of activity]. Vestnik Moskovskogo Universiteta. Ser. 14. Psikhologiya, n. 4, p. 14-24, 1979.

ZAPOROZHETS, A. V.; ELKONIN, D. B. Problemy detskoy psikhologii v trudakh A N Leont'yeva and A N Leontiev i sovremennaya psikhologiya (Sbornik statey pamyati A N Leont'yeva) [Problems of child psychology in the works of A $\mathrm{N}$ Leontiev and A.N. Leontiev and modern psychology (Collection of articles by the memory of A N Leontiev)]. Trad. A. V. Zaporozhets; V. P. Zinchenko; O. V. Ovchinnikova. Moscow: Izd-vo Mosk, 1983, p. 66-78.

Received: 01 July 2019

Accepted: 30 Nov 2019

Cedes Editorial Committee/Coordination of this issue:

Silvia Cordeiro Nassif and Maria Silvia Pinto de Moura Librandi da Rocha 